\title{
An Explainable Artificial Intelligence Approach for Predicting Cardiovascular Outcomes using Electronic Health Records
}

${ }^{1 *}$ Sergiusz Wesołowski, ${ }^{1 *}$ Gordon Lemmon, ${ }^{1}$ Edgar J. Hernandez, ${ }^{1}$ Alex Henrie, ${ }^{2}$ Thomas A. Miller, ${ }^{2}$ Derek Weyhrauch, ${ }^{2}$ Michael D. Puchalski, ${ }^{3,7}$ Bruce E. Bray, ${ }^{3}$ Rashmee U. Shah, ${ }^{4}$ Vikrant G. Deshmukh, ${ }^{5}$ Rebecca Delaney, ${ }^{6} \mathrm{H}$. Joseph Yost, ${ }^{7}$ Karen Eilbeck,

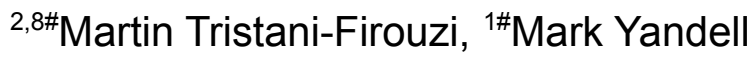

${ }^{1}$ Department of Human Genetics and Utah Center for Genetic Discovery, University of Utah, Salt Lake City, UT, USA;

${ }^{2}$ Division of Pediatric Cardiology, University of Utah School of Medicine, Salt Lake City, UT, USA;

${ }^{3}$ Division of Cardiovascular Medicine, University of Utah School of Medicine, Salt Lake City, UT, USA

${ }^{4}$ University of Utah Health Care CMIO Office, Salt Lake City, UT, USA.

${ }^{5}$ Department of Population Health Sciences, University of Utah, Salt Lake City, UT, USA;

${ }^{6}$ Molecular Medicine Program, University of Utah, Salt Lake City, UT, 84112, USA.

${ }^{7}$ University of Utah, Biomedical Informatics, Salt Lake City, UT 84108, USA.

${ }^{8}$ Nora Eccles Harrison CVRTI, University of Utah School of Medicine, Salt Lake City, UT, USA;

*equal contribution

\#Corresponding Authors: Martin.Tristani@utah.edu, myandell@genetics.utah.edu 
medRxiv preprint doi: https://doi.org/10.1101/2021.07.21.21260474; this version posted July 22, 2021. The copyright holder for this preprint (which was not certified by peer review) is the author/funder, who has granted medRxiv a license to display the preprint in perpetuity. It is made available under a CC-BY-NC-ND 4.0 International license .

\section{Abstract}

Understanding the conditionally-dependent clinical variables that drive cardiovascular health outcomes is a major challenge for precision medicine. Here, we deploy a recently developed massively scalable comorbidity discovery method called Poisson Binomial based Comorbidity discovery (PBC), to analyze Electronic Health Records (EHRs) from the University of Utah and Primary Children's Hospital (over 1.6 million patients and 77 million visits) for comorbid diagnoses, procedures, and medications. Using explainable Artificial Intelligence (AI) methodologies, we then tease apart the intertwined, conditionally-dependent impacts of comorbid conditions and demography upon cardiovascular health, focusing on the key areas of heart transplant, sinoatrial node dysfunction and various forms of congenital heart disease. The resulting multimorbidity networks make possible wide-ranging explorations of the comorbid and demographic landscapes surrounding these cardiovascular outcomes, and can be distributed as web-based tools for further community-based outcomes research. The ability to transform enormous collections of EHRs into compact, portable tools devoid of Protected Health Information solves many of the legal, technological, and data-scientific challenges associated with large-scale EHR analyzes.

\section{Introduction}

The application of data-science methods to electronic health record (EHR) databases promises a new, global perspective on human health, with widespread applications for outcomes research and precision medicine initiatives. However, unmet technological challenges still exist ${ }^{1-3}$. One is the need for improved means for ab initio discovery of 
medRxiv preprint doi: https://doi.org/10.1101/2021.07.21.21260474; this version posted July 22, 2021. The copyright holder for this preprint (which was not certified by peer review) is the author/funder, who has granted medRxiv a license to display the preprint in perpetuity. It is made available under a CC-BY-NC-ND 4.0 International license .

comorbid clinical variables in the context of confounding demographic variables at scale. Moreover, how best to tease apart the intertwined impacts of multiple comorbidities and demographic variables on patient health remains a daunting challenge $e^{1,2,4-9}$

We used a massively-scalable comorbidity discovery method called Poisson Binomial based Comorbidity (PBC) discovery ${ }^{10}$ to search Electronic Health Records (EHRs) from the University of Utah and Primary Children's Hospital (over 1.6 million patients and 77 million visits) for comorbid diagnoses, procedures, and medications. In this context, we refer to co-occurring medical diagnoses, procedures and medications using the single blanket term, comorbidity. PBC can also discover temporal relationships and quantify transition rates between various comorbidities. The result is a disease network, devoid of Protected Health Information (PHI), that is well-suited for powering downstream outcomes research.

Although comorbidity discovery is a necessary first step towards enabling outcomes research, it is not an end in itself. Comorbidities do not exist as isolated pairs, rather they combine to create a complex web of influence on any given outcome. While PBC is powered to discover that web, harnessing it for outcomes research requires a separate computational machinery, one capable of calculating the joint contributions of multiple, conditionally dependent variables on an outcome, so called multimorbidity calculations $^{2,11-13}$. Moreover, because researchers seek not merely to predict outcomes, but also to measure the contributions of factors driving them, 'explainable' solutions ${ }^{14-22}$, 
medRxiv preprint doi: https://doi.org/10.1101/2021.07.21.21260474; this version posted July 22, 2021. The copyright holder for this preprint (which was not certified by peer review) is the author/funder, who has granted medRxiv a license to display the preprint in perpetuity. It is made available under a CC-BY-NC-ND 4.0 International license .

rather than black box approaches are required. We have adapted Probabilistic Graphical Models (PGMs) $)^{3,22-27}$ to address these needs.

PGMs are well suited for outcomes research. Contrary to other methods, like e.g. generalized linear models (with or without mixed effects), PGMs are capable of: (1) discovering and modelling any number of multilevel dependencies between variables, (2) capturing non-additive or non-multiplicative interactions, and (3) their application does not require excluding nor imputing missing data ${ }^{28}$. Moreover, PGMs model the full joint probability function governing relations in the data, and thus do not necessitate a dichotomy between response and input variables. Rather, PGMs are capable of answering a prediction query for any variables conditioned on any set of inputs included in the model.

Using these computational technologies, we mined the EHRs of over 1.6 million University of Utah and Primary Children's Hospital patients, including over 500,000 mother-child pairs, for comorbid diagnoses, procedures, medications, and lab tests driving diverse cardiovascular health outcomes, focusing on three areas: heart transplant, sinoatrial node dysfunction, and congenital heart disease. Our results illuminate the comorbid and demographic landscapes surrounding these key cardiovascular outcomes in the US intermountain west, and demonstrate how our approach can inform health care disparities with precise, quantitative results in the context of a specific health care system. 
medRxiv preprint doi: https://doi.org/10.1101/2021.07.21.21260474; this version posted July 22, 2021. The copyright holder for this preprint (which was not certified by peer review) is the author/funder, who has granted medRxiv a license to display the preprint in perpetuity. It is made available under a CC-BY-NC-ND 4.0 International license .

\section{Results}

\section{$P B C$ is well powered for discovery of cardiovascular comorbidities.}

Table 1 demonstrates the utility of the PBC approach for discovery, by comparing the power of PBC versus a standard stratification approach (followed by $x^{2)}$ to detect the well documented comorbid relationship between atrial fibrillation (AF) and acute cerebrovascular disease (stroke $)^{29,30}$. Table 1 provides a power analysis as a function of corpus size and number of demographic variables. The effects of stratifying the data for $\mathrm{X}^{2}$ analysis, versus adding them to the PBC calculation, can be observed as one proceeds down the table columns. Results for three different starting cohort sizes are shown. Note how stratification lowers the strength of $p$-values as a function of the size of the stratum. This effect is exacerbated when more than a few potentially confounding variables are controlled for, and stratification quickly results in cohorts that are too small for discovery activities, as the comorbidities fail to achieve statistical significance. For example, using a starting corpus of 9,525 records, stratification followed by $x^{2}$ analysis fails to detect the well-known comorbid relationship between AF and Stroke for female patients aged 50-59 when Caucasian ancestry is included in the stratum description. By contrast, the PBC approach maintains power across all comparisons. For more on these points, see ${ }^{10}$.

\section{Comorbidities of heart transplant}

We evaluated every pairwise combination of diagnoses, procedures, and medications mentioned in our EHR corpus for comorbid associations, using $\mathrm{PBC}^{10}$ to adjust on a patient-by-patient basis for the potentially confounding demographic variables shown in 
medRxiv preprint doi: https://doi.org/10.1101/2021.07.21.21260474; this version posted July 22, 2021. The copyright holder for this preprint (which was not certified by peer review) is the author/funder, who has granted medRxiv a license to display the preprint in perpetuity. It is made available under a CC-BY-NC-ND 4.0 International license .

Figure 1. Figure 2A summarizes the results of this computation as a patient disease network. The network provides a visual overview of the entire EHR corpus, wherein every node (state) is a diagnosis, procedure, or medication, and edges denote Bonferroni significant comorbid relations between terms.

Given a node of interest, heart transplant, for example, its comorbid diagnoses and associated procedures and medications can be recovered by following edges to that node back to their terms.

The transition probabilities associated with each edge provide means to calculate the pairwise contributions of each term to the outcome's observed (marginal) frequency in the EHR corpus. This provides a way to intuit an outcome's comorbidity landscape, and calculate the expected flux of patients through that region of the network. These patient 'trajectories' provide a framework for cost prediction and service allocation activities. For example, the trajectory for adult heart transplant (Figure 2B) tracks the time course of diagnoses, procedures and medication use preceding and following heart transplantation. Thus, one can follow the trajectory of ischemic heart disease, flowing through the diagnosis of heart failure, cardiogenic shock, administration of the vasoactive medication milrinone, and culminating in heart transplantation with subsequent downstream complications. Crucially, this methodology provides precise measures of patient flux between these nodes.

\section{Multimorbidity network for heart transplant supports conditional outcome risk calculations}

Although trajectories provide intuitive and useful overviews of the comorbidity landscape, effective outcomes research requires calculating the joint contributions of 
medRxiv preprint doi: https://doi.org/10.1101/2021.07.21.21260474; this version posted July 22, 2021. The copyright holder for this preprint (which was not certified by peer review) is the author/funder, who has granted medRxiv a license to display the preprint in perpetuity. It is made available under a CC-BY-NC-ND 4.0 International license .

conditionally dependent multimorbid terms on an outcome. We leverage Probabilistic Graphical Models as an explainable Al solution for this computationally intensive task.

Figure 3A illustrates a multimorbidity network derived from a temporalized Probabilistic Graphical Model for the predisposing comorbidities of adult heart transplant presented in Figure 2B. Because the edges in a multimorbidity network denote conditional dependencies between terms, rather than transition probabilities, the multimorbidity network's topology is necessarily different from the trajectory topology shown in Figure 2B. The PGM provides easy means to calculate outcomes risk for any combination of variables in it. For example, a prior diagnosis of cardiomyopathy (non-ischemic) increases the risk of heart transplantation $86 \pm 35$ fold, whereas a diagnosis of viral myocarditis confers a $59 \pm 21$ fold increase in risk. The strongest single variable for heart transplant risk is the use of the vasoactive medication milrinone, which increases risk $175 \pm 30$ fold. Note that we are not suggesting milrinone causes heart transplant - rather that the prescription of milrinone in a patient's medical record is a powerful predictor of future heart transplant.

The utility of PGMs for outcomes research is best illustrated by their application to problems of complex multimorbid outcomes analyses, where conditional dependencies of these variables interact to further modulate risk for the outcome under study. For example, we can explore the role of heart disease etiology on transplant risk in the context of milrinone infusion. Thus, a cardiomyopathy patient requiring milrinone has a $407 \pm 101$ fold increased risk for heart transplant. Likewise, a patient with viral myocarditis requiring milrinone therapy has a $346 \pm 93$ fold increased risk for heart transplant; while milrinone use in a patient with ischemic heart disease confers a 
medRxiv preprint doi: https://doi.org/10.1101/2021.07.21.21260474; this version posted July 22, 2021. The copyright holder for this preprint (which was not certified by peer review) is the author/funder, who has granted medRxiv a license to display the preprint in perpetuity. It is made available under a CC-BY-NC-ND 4.0 International license .

$205 \pm 28$ fold increased risk of heart transplant. Moreover, while both cardiomyopathy and ischemic heart disease have similar increased risks for heart transplant in isolation (86 \pm 35 fold and $64 \pm 14$ fold, respectively), cardiomyopathy patients who require milrinone therapy are at far greater risk for heart transplant than patients with ischemic heart disease requiring milrinone. Additional conditional queries conducted with the PGM are presented in Fig 3A. This list is by no means exhaustive - the PGM is capable of answering an astonishing number of queries $-3^{25}$ to be precise. We encourage the reader to explore these by following the link to the corresponding web application https://pbc.genetics.utah.edu/lemmon2021/bayes/bayes. In this context, the explainable nature of PGMs lays the foundation for massively parallel testing of novel hypotheses between multiple, complex clinical variables of interest.

The comorbidity landscape for pediatric heart transplant is dramatically different from that of adults, as it includes a large contribution from congenital heart defects (CHD) and palliative surgical procedures. Figure 3B presents a multimorbidity network for 13 common CHD terms defined by echocardiogram and identified by PBC as comorbid with pediatric heart transplant. A prior diagnosis of dilated cardiomyopathy (DCM), defined as genetic/idiopathic DCM, increases a child's risk for heart transplant 102.2 \pm 33.6 -fold, over the marginal probability of transplant. Among single ventricle forms of CHD, patients with hypoplastic left heart syndrome (HLHS) are at the greatest risk for heart transplant $(56.8 \pm 17.8-$ fold $)$, as compared to tricuspid atresia (17.1 \pm 11.8 -fold) or laterality defects $(25.8$-fold \pm 8.5$)$. Again, the utility of PGMs for complex multimorbid analyses is highlighted by the ability to calculate the additional risk 
medRxiv preprint doi: https://doi.org/10.1101/2021.07.21.21260474; this version posted July 22, 2021. The copyright holder for this preprint (which was not certified by peer review) is the author/funder, who has granted medRxiv a license to display the preprint in perpetuity. It is made available under a CC-BY-NC-ND 4.0 International license .

for heart transplant in a child with a laterality defect, if that child also requires the Norwood surgery (51.3 \pm 10.5 -fold).

Multimorbidity network for sinoatrial node dysfunction supports multimorbidity risk calculations for a range of clinical and demographic health predictors

Figure 4A extends the investigations to include the impacts of these same pediatric heart surgeries in the context of various CHD phenotypes on a different clinical outcome, sinoatrial node dysfunction (SND). The Fontan surgery dominates the landscape of pediatric SND, increasing the risk $19.6 \pm 6.4$-fold over the marginal probability of SND. Moreover, Fontan surgery is the only clinical variable with a direct connection to SND; the other clinical variables connect indirectly to SND via the Fontan node. Thus, the relative risk of SND for specific forms of single ventricle CHD (HLHS, tricuspid atresia, unbalanced AVSD) following the Fontan surgery are similar (Figure 4 Table), indicating that the Fontan surgery itself is the primary indicator of future SND, rather than the underlying form of $\mathrm{CHD}$ that required the procedure. Collectively, the preceding analyses demonstrate how multiple nets can be used in tandem to address complex multimorbidity outcomes questions.

Multimorbidity networks also provide powerful means to investigate the impacts of various demographic factors upon outcomes. The net in Figure 4B models the multimorbid landscape surrounding SND in adult patients. As SND and AF are both risk factors for each other ${ }^{31}$, we temporalized the network (see Methods) to analyze clinical variables that precede SND. The ancestry and ethnicity nodes enable explorations of demographic impacts upon SND and its comorbidities. Thus, in the University of Utah Hospital system, a Hispanic patient with AF has a $61 \pm 6$ fold increased risk of SND, 
medRxiv preprint doi: https://doi.org/10.1101/2021.07.21.21260474; this version posted July 22, 2021. The copyright holder for this preprint (which was not certified by peer review) is the author/funder, who has granted medRxiv a license to display the preprint in perpetuity. It is made available under a CC-BY-NC-ND 4.0 International license .

compared to $30 \pm 1$ fold risk for Caucasians and $40 \pm 7$ fold risk for African Americans. These results underscore the potential of our approach to inform ethnic/racial health care disparities with precise, quantitative results, and in the context of a specific health care system. Moreover, these findings illustrate how our approach can empower these discussions despite demographic skews in the underlying EHR corpus (see Supplementary Tables 2 and 3); an important finding for the Utah health system.

\section{Multimorbidities of congenital malformations augmented by maternal health data}

The impact of maternal health on health outcomes in the child is an area of intense investigation. The Multimorbidity network shown in Figure 5A places a child's risk for congenital malformations in the context of a maternal diagnosis of pregnancy-induced hypertension (HTN-PREG) during that pregnancy, leveraging outcomes data for over 130,000 births at the University of Utah Hospital system over the last 15 years. HTN-PREG elevates the risk of cardiac and circulatory congenital anomalies 1.83 \pm 0.03 -fold, an effect not due to maternal age differences (Supplemental Figure 1). The multimorbidity network also illuminates the strong dependencies between clinical variables and allows for quantitative assessments of risk. For example, a diagnosis of Down Syndrome is associated with a $25.9 \pm 0.8$-fold increased risk for a congenital cardiac anomaly (Supplemental Table 4A). Moreover, a child with a congenital cardiac anomaly is a priori $9.2 \pm 0.9$-fold more likely to have a nervous system anomaly than baseline (Supplemental Table 4B). The impact of maternal health on a child's risk of CHD is further explored in Figure 5B. Our ability to seamlessly combine and compute upon maternal/child EHR data highlights the extensibility of our approach to study 
medRxiv preprint doi: https://doi.org/10.1101/2021.07.21.21260474; this version posted July 22, 2021. The copyright holder for this preprint (which was not certified by peer review) is the author/funder, who has granted medRxiv a license to display the preprint in perpetuity. It is made available under a CC-BY-NC-ND 4.0 International license .

health outcomes across generations in order to define the impacts of maternal health on childhood outcomes.

\section{Web-based outcomes calculators}

We repackaged the multimorbidity networks as stand-alone web-based outcomes calculators. This allows users to interact with a multimorbidity network as an 'app', whereby they can use slider buttons to toggle values of its states and to select an outcome of interest. These web-apps are available here:

\section{https://pbc.genetics.utah.edu/lemmon2021/bayes/bayes}

\section{Discussion}

The ability to model dependencies among multiple risk factors is crucial for meaningful outcomes research. Unfortunately, traditional techniques, such as logistic regression, have limited ability to capture so-called 'conditional dependencies' between variables, which are the heart and soul of multimorbid analyses. Although mixture and generalized linear models with mixed effects can (in principle) overcome this weakness, these techniques are limited because a new model must be designed for every question. Neural nets provide one possible alternative. But although they can account for non-linear interactions in the data and are scalable ${ }^{7}$, Neural nets are often referred to as 'black boxes' (i.e., lacking explainability) ${ }^{14,15,20,21,32-35}$ due to the difficulties in determining precisely how and why different input variables were used to produce the outputs. Because we sought not merely to predict outcomes, but also to understand the relationships between multiple clinical variables and outcomes, we selected an 'explainable' Al solution, rather than a black box approach. Probabilistic Graphical 
medRxiv preprint doi: https://doi.org/10.1101/2021.07.21.21260474; this version posted July 22, 2021. The copyright holder for this preprint (which was not certified by peer review) is the author/funder, who has granted medRxiv a license to display the preprint in perpetuity. It is made available under a CC-BY-NC-ND 4.0 International license .

Model-based ${ }^{23-25}$ multimorbidity networks offer best-practice solutions to this problem. Moreover, they effectively model data without recourse to a fixed decision protocol (i.e. decision trees), and are resilient to missing/unknown data. Crucially, the contributions of different combinations of variables to an outcome can be precisely and easily determined. This explainability comes at a cost, however. Unlike Neural nets, which are incredibly scalable, multimorbidity networks can model a maximum of only 30 or so variables at once ${ }^{28,36,37}$. It is therefore necessary to pre-identify high impact variables when modeling an outcome, a need fulfilled by $\mathrm{PBC}^{10}$. We argue that the ability to rigorously investigate interrelations among 30 or so primary determinants represents a giant step forward towards understanding cardiovascular disease outcomes.

Our results illustrate how multimorbidity networks provide explainable solutions for understanding the joint impacts of diagnoses, medications, and medical procedures on cardiovascular health outcomes. We emphasize that the necessarily brief results reported here hardly exhaust the contents of these machineries. Consider that a multimorbidity network with $n$ nodes supports $\sim 3^{n}$ possible queries. The net shown in Figure 4B, for example, supports $\sim 3^{14}$ different queries-a number that gives some indication both of the complexity of the data being extracted from the EHR corpus by our approach, and the value of these multimorbidity networks to further outcomes research. The analyses presented here provide a first step toward a global description of heart disease and associated comorbidities across the USA intermountain west. However, the map we seek resides not so much in the results reported here, as it does in the products of our analyses: the PGMs multimorbidity networks. As we have explained, these networks support multitudes of queries, and when used in 
medRxiv preprint doi: https://doi.org/10.1101/2021.07.21.21260474; this version posted July 22, 2021. The copyright holder for this preprint (which was not certified by peer review) is the author/funder, who has granted medRxiv a license to display the preprint in perpetuity. It is made available under a CC-BY-NC-ND 4.0 International license .

combination, support both wide-ranging and focused explorations of a disease landscape. A major strength of our approach is that these outcomes machineries can be redistributed as web-based tools. Indeed, the multimorbidity Networks described here have been made available online [pbc.genetics.utah.edu/lemmon2021/bayes/bayes], with the hope that the wider scientific community will find them useful for their own outcomes research. The ability to transform enormous collections of EHR data into compact, portable machines for outcomes research, with no exchange of $\mathrm{PHI}$, solves many of the legal, technological, and data-scientific challenges associated with large-scale EHR analyses.

\section{Methods}

\section{Ethics Statement}

Human subjects approval for this study was obtained following review by the University of Utah Institutional Review Board, IRB_00095807. All authors completed Human Subjects research requirements.

\section{Utah Data Resource}

The University of Utah maintains an Enterprise Data Warehouse (EDW) - a central storage and search facility for all clinical data collected from all affiliated University hospitals and clinics across the Intermountain West. SQL queries were used to aggregate data from various tables and collect the following information: (1) gender, ancestry, ethnicity, and age for each patient; (2) list of patient visits, along with visit dates, and medical terms associated with each visit, including diagnostic codes, procedure codes, and medications ordered. ICD9 and ICD10 diagnosis codes consist of 
medRxiv preprint doi: https://doi.org/10.1101/2021.07.21.21260474; this version posted July 22, 2021. The copyright holder for this preprint (which was not certified by peer review) is the author/funder, who has granted medRxiv a license to display the preprint in perpetuity. It is made available under a CC-BY-NC-ND 4.0 International license .

18,000 and 142,000 codes respectively, while procedural codes (CPT) include around 10,000 codes. In all, we collected records for 1.6 million patients, 21 million visits and 166 million diagnosis (DX), procedure $(P X)$ and medication $(R X)$ codes. See Supplemental Tables 1 and 2 for additional details.

We combined these data with the Primary Children's Hospital's database of echocardiographic variables (diagnoses, ventricular function, valve gradients, chamber/vessel sizes, etc.) dating back to 2006 for 65,618 probands, 44,254 of which also appear longitudinally in the University's EDW. These data contain 529,317 mother-child pairs with EHR data, 14,155 of which include a child with echo data, allowing us to study maternal contributions to congenital heart disease (CHD). Collectively, these data comprise the Utah Data Resource (UDR). For the purposes of computation, custom encryption is applied to the UDR to produce data free of protected health information $(\mathrm{PHI})$ and unintelligible without its cyphers. We can then generate statistics on this $\mathrm{PHI}$ free data in a variety of compute environments, decrypting the results on $\mathrm{PHI}$ approved machines.

In this analysis, a patient's diagnoses are inferred via billing codes. Thus, the investigations and risk calculations presented herein reflect medical practice within the University of Utah Hospital network and Primary Children's Healthcare. How closely they approximate underlying universal ('true') risks is still unknown. Moving forward, we note that the methods described below provide powerful means for large-scale cross institutional comparisons aimed at discovering differences in medical practice and billing trends. 
medRxiv preprint doi: https://doi.org/10.1101/2021.07.21.21260474; this version posted July 22, 2021. The copyright holder for this preprint (which was not certified by peer review) is the author/funder, who has granted medRxiv a license to display the preprint in perpetuity. It is made available under a CC-BY-NC-ND 4.0 International license .

\section{Patient Disease Network}

We used PBC to find significant connections among every possible combination of ICD diagnoses, procedures, and RxNorm ${ }^{38}$ medication terms in our EHR corpus, thereby creating a patient disease network. Patient disease network is a term borrowed from Capobianco et. $\mathrm{al}^{1}$ and comprises all significant connections among diagnoses, procedures and medications (Bonferroni p-value cutoff 10E-9.48). We only consider terms appearing in at least 15 patients. This filter reduces the number of unique terms to 39,055 ICD10 diagnosis codes, 5,716 CPT procedure codes, and 1,764 RxNorm medication codes. We used Minimum Description Length clustering ${ }^{39}$ to visualize the data, so that nodes with similar combinations of edges would lay near one another in the network. We also determined the patient flux between every pair of nodes. The result is shown in Figure 2A, which provides a visual representation of our patient disease network for the entire EHR corpus.

In keeping with previous work $^{13,40-43}$ on patient disease networks, we refer to a sub-portion of the network, focused on a single outcome as a trajectory, or term trajectory. Figure 2B shows a trajectory for adult heart transplant. Trajectories provide means to display additional features of the network, such as transition probabilities (which correspond to patient flux between nodes), and the marginal frequencies of outcomes and comorbid terms within the EHR corpus. Collectively, this information allows for better intuition of the disease landscape surrounding an outcome. The trajectory is also a useful starting point for cost and service allocation calculations. 
medRxiv preprint doi: https://doi.org/10.1101/2021.07.21.21260474; this version posted July 22, 2021. The copyright holder for this preprint (which was not certified by peer review) is the author/funder, who has granted medRxiv a license to display the preprint in perpetuity. It is made available under a CC-BY-NC-ND 4.0 International license .

\section{Multimorbidity Networks}

While trajectories describe transition probabilities between two comorbid terms, they provide no means to determine the combined effects of multiple comorbid diagnoses, and associated clinical procedures and medications upon an outcome. We have employed Probabilistic Graphical Models to overcome this limitation. We have learned the structures of the Probabilistic Graphical Models using the python3 package "pomegranate"28, which provides a Bayesian Information Criterion (BIC)-based DP-A* exact structure search algorithm ${ }^{36,37}$. The exact search algorithm explores the entire applicable space of conditional dependencies in order to discover the optimal network structure for the data. Parameter learning for this optimal network is accomplished using the loopy belief propagation algorithm ${ }^{44}$. We use the same package for our inference and multimorbidity risk calculations. The visual interpretation was designed using the graph_tool ${ }^{45}$ Python3 package and D3.js Java library.

For each Probabilistic Graphical Model, a maximum of 25 comorbid features were selected and validated by an expert in the medical field. The underlying Probabilistic Graphical Model was learned and trained on the patient data with the retrieved features. The patient's features were described in a categorical data format, (e.g. indicating the ancestry, ethnicity, or insurance type) or "present/absent" binary variables in case of medical diagnoses and procedures. Additionally, any continuous feature (e.g. age, BMI, blood pressure), can be also incorporated in the PGM upon discretization based on establish clinical practice. Because the PGMs only present the facts about the data, PGMs themselves cannot discover or infer the temporal order of the events (unless specified in as a Dynamic PGM - results not presented). To overcome this issue, for our 
medRxiv preprint doi: https://doi.org/10.1101/2021.07.21.21260474; this version posted July 22, 2021. The copyright holder for this preprint (which was not certified by peer review) is the author/funder, who has granted medRxiv a license to display the preprint in perpetuity. It is made available under a CC-BY-NC-ND 4.0 International license .

temporized PGMs we have imposed the order (discovered using PBC) on the EHR extraction process prior to learning the Probabilistic Graphical Model structure. When trained on temporalized data, PGMs are forced to learn temporal conditional probabilities. Missing data are handled inherently by the Probabilistic Graphical Model structure learning process. That is, no patients were excluded due to missing data and no missing data was imputed. The resulting temporalized structures we call multimorbidity networks.

Probabilistic Graphical Models represent conditional dependencies in the dataset as a directed acyclic graph (DAG); however, it is important not to confuse directionality with causality or temporal ordering. In keeping with best practice, the multimorbidity networks are visualized in their undirected, moralized form, in which every node is connected to its Markov blanket. A single constructed multimorbidity Network provides an inference engine capable of answering $\mathrm{O}\left(3^{\mathrm{n}}\right)$ personalized conditional risk queries, where $\mathrm{n}$ denotes the number of features describing a patient's condition, and the base of the exponent is 3 , because in case of binary health records data there are three states for each node that can be specified: present, absent, or status unknown.

\section{Confidence values}

Risk estimates derived from Probabilistic Graphical Models are maximum likelihood estimates given the optimal structure under the BIC and an assumed uniform prior probability of any distinct EHR. To obtain standard deviation values for these estimates, we created 100 nets in paralle $\left.\right|^{46}$ from bootstrap replicates of the same data used to create Figures 3, 4 and 5. We then queried the resulting replicate nets, and calculated standard deviations of risks of outcomes of interest. 


\section{Acknowledgements}

We thank Barry Moore, Jacob Shreiber, Jerry Rudisin, Sepideh Ebadi, Edward B. Clark and members of the University of Utah EDW, UPDB and Utah Center for High Performance Computing for insightful discussions, facilitating access to medical records and familial relationships, and computational support. This research was supported by the AHA Children's Strategically Focused Research Network grant (17SFRN33630041) and the Nora Eccles Treadwell Foundation. Rebecca Delaney's effort was supported by the National Institutes of Health under Ruth L. Kirschstein National Research Service Award T32 HL007576 from the National Heart, Lung, and Blood Institute. Gordon Lemmon was supported by NRSA training grant T32H757632. Sergiusz Wesolowski was supported by NRSA training grant T32DK110966-04.

\section{Competing interests}

GL, VD, MY own shares in Backdrop Health, there are no financial ties regarding this research.

\section{Reporting summary}

Further information on research design is available in the Nature Research Reporting Summary linked to this article. 
medRxiv preprint doi: https://doi.org/10.1101/2021.07.21.21260474; this version posted July 22, 2021. The copyright holder for this preprint (which was not certified by peer review) is the author/funder, who has granted medRxiv a license to display the preprint in perpetuity. It is made available under a CC-BY-NC-ND 4.0 International license .

\section{Data availability}

All Probabilistic Graphical Models described in this paper are available through the web using the following link: [https://pbc.genetics.utah.edu/lemmon2021/bayes/bayes.

\section{Author Contributions}

Study design: GL, SW, EJH, AH, BEB, RUS, VGD, RD, KE, MTF, MY; Data procurement or curation: GL, SW, EJH, AH, TAM, MDP, BEB, RUS, VGD, RD, KE, MTF, MY; Data analysis and interpretation: GL, SW, EJH, TAM, BEB, RUS, VGD, RD, HJY, KE, MTF, MY; Manuscript writing/editing: GL, SW, EJH, TAM, DW, MDP, BEB, RUS, VGD, RD, HJY, KE, MTF, MY.

\section{References}

1. Capobianco, E. \& Lio', P. Comorbidity: a multidimensional approach. Trends Mol. Med. 19, $515-521(2013)$.

2. Valderas, J. M., Starfield, B., Sibbald, B., Salisbury, C. \& Roland, M. Defining Comorbidity: Implications for Understanding Health and Health Services. Ann. Fam. Med. 7, 357-363 (2009).

3. Kraisangka, J. et al. Bayesian Network vs. Cox's Proportional Hazard Model of PAH Risk: A Comparison. in Artificial Intelligence in Medicine (eds. Riaño, D., Wilk, S. \& ten Teije, A.) 139-149 (Springer International Publishing, 2019). doi:10.1007/978-3-030-21642-9_19.

4. Guo, M. et al. Analysis of disease comorbidity patterns in a large-scale China population. BMC Med. Genomics 12, 177 (2019).

5. Hu, J. X., Thomas, C. E. \& Brunak, S. Network biology concepts in complex disease comorbidities. Nat. Rev. Genet. 17, 615-629 (2016). 
medRxiv preprint doi: https://doi.org/10.1101/2021.07.21.21260474; this version posted July 22, 2021. The copyright holder for this preprint

(which was not certified by peer review) is the author/funder, who has granted medRxiv a license to display the preprint in perpetuity.

It is made available under a CC-BY-NC-ND 4.0 International license .

6. Akram, P. \& Liao, L. Prediction of comorbid diseases using weighted geometric embedding of human interactome. BMC Med. Genomics 12, 161 (2019).

7. Rank, N. et al. Deep-learning-based real-time prediction of acute kidney injury outperforms human predictive performance. Npj Digit. Med. 3, 1-12 (2020).

8. Gutiérrez-Sacristán, A. et al. comoRbidity: an R package for the systematic analysis of disease comorbidities. Bioinformatics 34, 3228-3230 (2018).

9. Moni, M. A. \& Liò, P. comoR: a software for disease comorbidity risk assessment. J. Clin. Bioinforma. 4, 8 (2014).

10. Lemmon, G. H., Wesolowski, S., Henrie, A., Yandell, M. \& Tristani-Firouzi, M. A Poisson binomial based statistical testing framework for comprehensive comorbidity discovery across massive Electronic Health Record datasets. medRxiv 2021.07.14.21260532 (2021) doi:10.1101/2021.07.14.21260532.

11. Aguado, A., Moratalla-Navarro, F., López-Simarro, F. \& Moreno, V. MorbiNet: multimorbidity networks in adult general population. Analysis of type 2 diabetes mellitus comorbidity. Sci. Rep. 10, 2416 (2020).

12. Xu, H., Moni, M. A. \& Lio, P. CytoCom: A Cytoscape app to visualize, query and analyse disease comorbidity networks. Bioinforma. Oxf. Engl. 31, (2014).

13. Ronzano, F., Gutiérrez-Sacristán, A. \& Furlong, L. I. Comorbidity4j: a tool for interactive analysis of disease comorbidities over large patient datasets. Bioinformatics 35, 3530-3532 (2019).

14. Barredo Arrieta, A. et al. Explainable Artificial Intelligence (XAI): Concepts, taxonomies, opportunities and challenges toward responsible Al. Inf. Fusion 58, 82-115 (2020).

15. Amann, J. et al. Explainability for artificial intelligence in healthcare: a multidisciplinary perspective. BMC Med. Inform. Decis. Mak. 20, 310 (2020).

16. Anguita-Ruiz, A., Segura-Delgado, A., Alcalá, R., Aguilera, C. M. \& Alcalá-Fdez, J. eXplainable Artificial Intelligence (XAI) for the identification of biologically relevant gene 
medRxiv preprint doi: https://doi.org/10.1101/2021.07.21.21260474; this version posted July 22, 2021. The copyright holder for this preprint

(which was not certified by peer review) is the author/funder, who has granted medRxiv a license to display the preprint in perpetuity.

It is made available under a CC-BY-NC-ND 4.0 International license .

expression patterns in longitudinal human studies, insights from obesity research. PLoS

Comput. Biol. 16, e1007792 (2020).

17. Gordon, L., Grantcharov, T. \& Rudzicz, F. Explainable Artificial Intelligence for Safe Intraoperative Decision Support. JAMA Surg. 154, 1064-1065 (2019).

18. Lamy, J.-B., Sekar, B., Guezennec, G., Bouaud, J. \& Séroussi, B. Explainable artificial intelligence for breast cancer: A visual case-based reasoning approach. Artif. Intell. Med. 94, 42-53 (2019).

19. Lauritsen, S. M. et al. Explainable artificial intelligence model to predict acute critical illness from electronic health records. Nat. Commun. 11, 3852 (2020).

20. London, A. J. Artificial Intelligence and Black-Box Medical Decisions: Accuracy versus Explainability. Hastings Cent. Rep. 49, 15-21 (2019).

21. Wang, H. et al. Predicting Hospital Readmission via Cost-Sensitive Deep Learning. IEEE/ACM Trans. Comput. Biol. Bioinform. 15, 1968-1978 (2018).

22. Arora, P. et al. Bayesian Networks for Risk Prediction Using Real-World Data: A Tool for Precision Medicine. Value Health 22, 439-445 (2019).

23. Neuberg, L. G. CAUSALITY: MODELS, REASONING, AND INFERENCE, by Judea Pearl, Cambridge University Press, 2000. Econom. Theory 19, 675-685 (2003).

24. Pearl, J. Reverend bayes on inference engines: a distributed hierarchical approach. in Proceedings of the Second AAAI Conference on Artificial Intelligence 133-136 (AAAI Press, 1982).

25. Pearl, J. Probabilistic Reasoning in Intelligent Systems: Networks of Plausible Inference. (Morgan Kaufmann Publishers Inc., 1988).

26. McLachlan, S., Dube, K., Hitman, G. A., Fenton, N. E. \& Kyrimi, E. Bayesian networks in healthcare: Distribution by medical condition. Artif. Intell. Med. 107, 101912 (2020).

27. Oniśko, A. \& Druzdzel, M. J. Impact of precision of Bayesian network parameters on accuracy of medical diagnostic systems. Artif. Intell. Med. 57, 197-206 (2013). 
medRxiv preprint doi: https://doi.org/10.1101/2021.07.21.21260474; this version posted July 22, 2021. The copyright holder for this preprint

(which was not certified by peer review) is the author/funder, who has granted medRxiv a license to display the preprint in perpetuity.

It is made available under a CC-BY-NC-ND 4.0 International license .

28. Schreiber, J. Pomegranate: fast and flexible probabilistic modeling in python. ArXiv171100137 Cs Stat (2018).

29. Wolf, P. A., Dawber, T. R., Thomas, H. E. \& Kannel, W. B. Epidemiologic assessment of chronic atrial fibrillation and risk of stroke: the Framingham study. Neurology 28, 973-977 (1978).

30. Wolf, P. A., Abbott, R. D. \& Kannel, W. B. Atrial fibrillation as an independent risk factor for stroke: the Framingham Study. Stroke 22, 983-988 (1991).

31. John, R. M. \& Kumar, S. Sinus Node and Atrial Arrhythmias. Circulation 133, 1892-1900 (2016).

32. Payrovnaziri, S. N. et al. Explainable artificial intelligence models using real-world electronic health record data: a systematic scoping review. J. Am. Med. Inform. Assoc. JAMIA 27, 1173-1185 (2020).

33. Rajkomar, A. et al. Scalable and accurate deep learning for electronic health records. Npj Digit. Med. 1, 18 (2018).

34. Franz, L., Shrestha, Y. R. \& Paudel, B. A Deep Learning Pipeline for Patient Diagnosis Prediction Using Electronic Health Records. ArXiv200616926 Cs (2020).

35. Miotto, R., Li, L., Kidd, B. A. \& Dudley, J. T. Deep Patient: An Unsupervised Representation to Predict the Future of Patients from the Electronic Health Records. Sci. Rep. 6, 26094 (2016).

36. Koivisto, M. \& Sood, K. Exact Bayesian Structure Discovery in Bayesian Networks. J. Mach. Learn. Res. 5, 549-573 (2004).

37. Yuan, C., Malone, O. \& Wu, X. Learning optimal Bayesian networks using $A^{*}$ search. in In Proceedings of the 22nd International Joint Conference on Artificial Intelligence (2011).

38. Liu, S., Ma, W., Moore, R., Ganesan, V. \& Nelson, S. RxNorm: prescription for electronic drug information exchange. IT Prof. 7, 17-23 (2005).

39. Rissanen, J. Paper: Modeling by shortest data description. Autom. J. IFAC 14, 465-471 
medRxiv preprint doi: https://doi.org/10.1101/2021.07.21.21260474; this version posted July 22, 2021. The copyright holder for this preprint

(which was not certified by peer review) is the author/funder, who has granted medRxiv a license to display the preprint in perpetuity. It is made available under a CC-BY-NC-ND 4.0 International license.

(1978).

40. Agusti, A. \& Faner, R. Lung function trajectories in health and disease. Lancet Respir. Med. 7, 358-364 (2019).

41. Burckhardt, P., Nagin, D. S. \& Padman, R. Multi-Trajectory Models of Chronic Kidney Disease Progression. AMIA Annu. Symp. Proc. AMIA Symp. 2016, 1737-1746 (2016).

42. Reed, E. \& Corner, J. Defining the illness trajectory of metastatic breast cancer. BMJ Support. Palliat. Care 5, 358-365 (2015).

43. Siggaard, T. et al. Disease trajectory browser for exploring temporal, population-wide disease progression patterns in 7.2 million Danish patients. Nat. Commun. 11, 4952 (2020).

44. Weiss, Y. Correctness of local probability in graphical models with loops. Neural Comput. $12,1-41(2000)$.

45. Peixoto, T. P. The graph-tool python library. 136152697 Bytes (2017) doi:10.6084/M9.FIGSHARE.1164194.

46. GNU Scientific Library Reference Manual - Read online. https://www.e-booksdirectory.com/details. php?ebook=3457. 
medRxiv preprint doi: https://doi.org/10.1101/2021.07.21.21260474; this version posted July 22, 2021. The copyright holder for this preprint (which was not certified by peer review) is the author/funder, who has granted medRxiv a license to display the preprint in perpetuity.

\section{Display items}

\begin{tabular}{|l|l|l|l|l|l|l|}
\hline \multirow{5}{*}{ Atrial Fibrillation and Acute Cerebrovascular Disease } \\
\hline \multirow{2}{*}{ Features } & $\begin{array}{l}\mid l \\
\mathrm{~N}=1,538,05\end{array}$ & $\mathrm{~N}=95,407$ & $\mathrm{~N}=9,525$ & $\mathrm{~N}=1,538,05$ & $\mathrm{~N}=95,407$ & $\mathrm{~N}=9,525$ \\
\hline no features & $1 \mathrm{e}-31020$ & $1 \mathrm{e}-1715$ & $1 \mathrm{e}-203$ & $1 \mathrm{e}-31020$ & $1 \mathrm{e}-1715$ & $1 \mathrm{e}-203$ \\
\hline +sex & $1 \mathrm{e}-31017$ & $1 \mathrm{e}-1955$ & $1 \mathrm{e}-215$ & $1 \mathrm{e}-16657$ & $1 \mathrm{e}-1125$ & $1 \mathrm{e}-147$ \\
\hline +age & $1 \mathrm{e}-25448$ & $1 \mathrm{e}-1589$ & $1 \mathrm{e}-200$ & $1 \mathrm{e}-1304$ & $1 \mathrm{e}-88.3$ & $1 \mathrm{e}-13.1$ \\
\hline +ancestry & $1 \mathrm{e}-14381$ & $1 \mathrm{e}-628$ & $1 \mathrm{e}-73.1$ & $1 \mathrm{e}-15.72$ & 1 & 1 \\
\hline +ethnicity & $1 \mathrm{e}-11357$ & $1 \mathrm{e}-806$ & $1 \mathrm{e}-110$ & $1 \mathrm{e}-12.25$ & 1 & 1 \\
\hline +insurance & $1 \mathrm{e}-11533$ & $1 \mathrm{e}-771$ & $1 \mathrm{e}-83$ & $1 \mathrm{e}-2.68$ & 1 & 1 \\
\hline +span & $1 \mathrm{e}-11325$ & $1 \mathrm{e}-698$ & $1 \mathrm{e}-84.1$ & $1 \mathrm{e}-1.75$ & 1 & 1 \\
\hline
\end{tabular}

Table 1. PBC is well powered for comorbidity discovery on demographically complex datasets, unlike stratification. Progressively smaller random samples were drawn from the Utah EHR corpus, such that each cohort is a subset of this larger precursor. $\mathrm{N}=$ the number of subjects in each cohort under consideration. Cells in the table contain p-values for the association between Atrial Fibrillation and Acute Cerebrovascular Disease (stroke), as calculated by PBC or $\chi 2$ (for stratification). P-values less than the Bonferroni corrected alpha (1e-9.5) are shown in light blue, while cells that do not pass the significance threshold are red. Stratum filters apply to the features' column, row by row as follows: no filters, female, 50-59 years of age, Caucasian, non-Hispanic, commercial insurance, minimum of 2 years of medical history. 


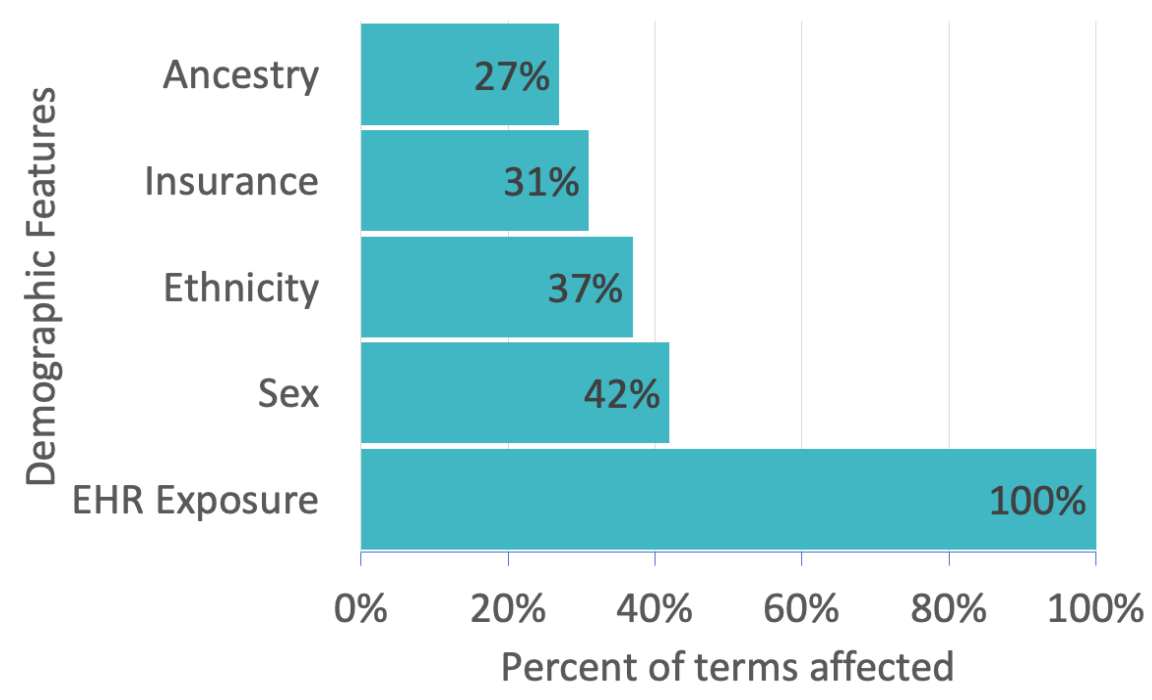

Figure 1. Percent of medical terms influenced by various demographic features. Demographic variables used in the comorbidity discovery process are displayed on the $y$-axis. The percent of all diagnoses, procedures, and medications influenced by a given demographic feature is displayed on the x-axis. For example, sex influences $42.2 \%$ percent of diagnoses, procedures, and medications in the Utah EHR corpus; ancestry influences $27.4 \%$ and EHR exposure 100\%. EHR exposure includes subject age, length of medical record history, number of visits. See article ${ }^{10}$ for details. Features were selected using L1 regularization. 
medRxiv preprint doi: https://doi.org/10.1101/2021.07.21.21260474; this version posted July 22, 2021. The copyright holder for this preprint (which was not certified by peer review) is the author/funder, who has granted medRxiv a license to display the preprint in perpetuity. It is made available under a CC-BY-NC-ND 4.0 International license .

A

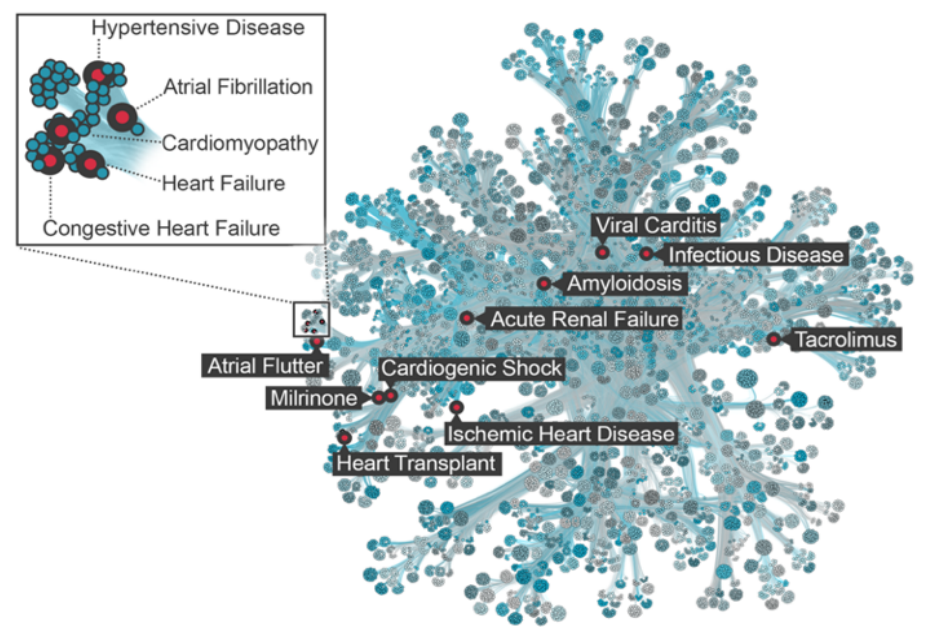

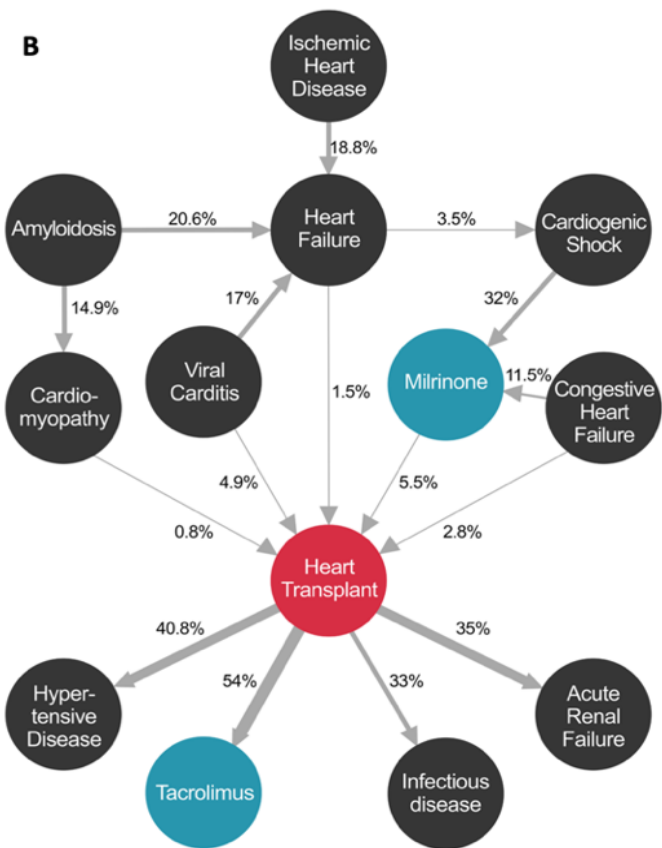

Figure 2. Patient Disease Network for the Utah Data Resource. Panel A. Graphical representation of the Patient Disease Network. 39,055 ICD 10 diagnosis codes, 5,716 CPT procedure codes, and 1,764 RxNorm medication codes comprising 50 million comorbidities are represented by the map. To render the patient disease network more readily interpretable, we utilized Minimum Description Length clustering, so that nodes with similar comorbidity patterns lay near to one another in the network. The comorbidities of Heart Transplant are labeled red for reference purposes. See methods for details. Panel B. Term trajectory for Adult Heart Transplant. Nodes represent diagnosis (black), procedures (red), and medications (blue). Edges are temporally ordered comorbidities (Bonferroni alpha $=10 \mathrm{E}-9.5)$, arrows denote direction. Edges are labeled with transition probabilities (e.g. patient flux). For example, an adult patient with viral myocarditis has a $17 \%$ chance of developing a heart failure diagnosis, and a $4.9 \%$ chance of undergoing heart transplantation. See Methods for additional details and Supplemental Table 5 for code references for the highlighted terms. 
medRxiv preprint doi: https://doi.org/10.1101/2021.07.21.21260474; this version posted July 22, 2021. The copyright holder for this preprint (which was not certified by peer review) is the author/funder, who has granted medRxiv a license to display the preprint in perpetuity.

It is made available under a CC-BY-NC-ND 4.0 International license .

A

\begin{tabular}{|c|c|c|c|}
\hline $\begin{array}{c}\text { CLINICAL } \\
\text { VARIABLES }\end{array}$ & RISK & $\begin{array}{c}\text { FOLD } \\
\text { CHANGE }\end{array}$ & PROBABILISTIC GRAPHICAL MODEL \\
\hline Milrinone & $0.054+/-0.009$ & $175+/-30$ & \\
\hline Cardiomyopathy & $0.026+/-0.011$ & $86+/-35$ & \\
\hline $\begin{array}{l}\text { Congestive Heart } \\
\text { Failure }\end{array}$ & $0.025+/-0.004$ & $81+/-14$ & \\
\hline Cardiogenic Shock & $0.05+/-0.03$ & $69+/-7$ & \\
\hline $\begin{array}{l}\text { Ischemic Heart } \\
\text { Disease }\end{array}$ & $0.019+/-0.004$ & $64+/-14$ & \\
\hline Viral Carditis & $0.018+/-0.006$ & $59+/-21$ & \\
\hline Heart Failure & $0.03+/-0.02$ & $48+/-12$ & \\
\hline Amyloidosis & $0.010+/-0.002$ & $34+1-7$ & \\
\hline $\begin{array}{l}\text { Cardiomyopathy } \\
+ \text { Milrinone }\end{array}$ & $0.125+/-0.036$ & $407+/-101$ & \\
\hline $\begin{array}{l}\text { Viral Carditis } \\
+ \text { Milrinone } \\
\end{array}$ & $0.106+/-0.028$ & $346+/-93$ & \\
\hline $\begin{array}{c}\text { Ischemic Heart } \\
\text { Disease + Milrinone }\end{array}$ & $0.063+/-0.010$ & $205+/-28$ & \\
\hline
\end{tabular}

B

\begin{tabular}{|c|c|c|c|}
\hline $\begin{array}{c}\text { CLINICAL } \\
\text { VARIABLES }\end{array}$ & RISK & $\begin{array}{c}\text { FOLD } \\
\text { CHANGE }\end{array}$ & PROBABILISTIC GRAPHICAL MODEL \\
\hline DCM & $0.273+/-0.122$ & $102.2+/-33.6$ & \\
\hline HLHS & $0.147+/-0.047$ & $56.8+/-17.8$ & \\
\hline Norwood & $0.096+/-0.031$ & $37.1+/-12.8$ & \\
\hline Glenn & $0.089+/-0.055$ & $34.3+/-21.8$ & \\
\hline Fontan & $0.068+/-0.041$ & $26.1+/-16.1$ & \\
\hline Laterality Defects & $0.067+/-0.022$ & $25.8+/-8.5$ & \\
\hline Tricuspid Atresia & $0.045+/-0.031$ & $17.1+/-11.8$ & \\
\hline AVSD & $0.014+/-0.014$ & $5.2+/-5.0$ & \\
\hline Coarctation & $0.006+/-0.002$ & $2.3+/-0.8$ & D \\
\hline ASD & $0.005+/-0.002$ & $1.9+/-0.7$ & \\
\hline VSD & $0.003+/-0.003$ & $1.3+/-1.2$ & $\mathrm{TO}$ \\
\hline TOF & $0.003+/-0.001$ & $1.0+/-0.1$ & \\
\hline BAV & $0.002+/-0.000$ & $0.7+/-0.1$ & VSD \\
\hline $\begin{array}{c}\text { Norwood }+ \\
\text { Laterality Defects }\end{array}$ & $0.124+/-0.028$ & $51.3+/-10.5$ & \\
\hline
\end{tabular}


medRxiv preprint doi: https://doi.org/10.1101/2021.07.21.21260474; this version posted July 22, 2021. The copyright holder for this preprint (which was not certified by peer review) is the author/funder, who has granted medRxiv a license to display the preprint in perpetuity.

It is made available under a CC-BY-NC-ND 4.0 International license.

Figure 3. Multimorbidity Landscape of Heart Transplant. Panel A. PGM for Adult Transplant. $\mathrm{N}=1.6$ million individuals. The clinical variables were chosen based on Bonferroni-corrected ICD10 and RXnorm billing codes significantly associated (preceding) with heart transplant. Each node represents a diagnosis, procedure, or medication code and each edge represents a conditional dependence between nodes. For detailed description of the clinical variables, please refer to supplemental table 5. Panel B. PGM for Pediatric Transplant. $\mathrm{N}=26,458$ individuals. Clinical variable terms represent terms in the Primary Children's Hospital echocardiographic database or CCS billing codes when available. For detailed description of the clinical variables, please refer to the supplemental table 5. DCM: Dilated cardiomyopathy; Norwood: Norwood surgery; HLHS: hypoplastic left heart syndrome; Glenn: Glenn surgery; Fontan: Fontan surgery; AVSD: atrioventricular septal defect; ASD: Atrial septal defect; BAV: Bicuspid aortic valve; Coarctation: Coarctation of the aorta; VSD: Ventricular septal defect. Heart Transplant is highlighted in orange. For $A$ and $B$, the target node (heart transplant) is colored red and nodes with direct connections to the target (ie, within the Markov blanket) are circled red. Values in Tables represent mean \pm STD. 
medRxiv preprint doi: https://doi.org/10.1101/2021.07.21.21260474; this version posted July 22, 2021. The copyright holder for this preprint (which was not certified by peer review) is the author/funder, who has granted medRxiv a license to display the preprint in perpetuity.

It is made available under a CC-BY-NC-ND 4.0 International license .

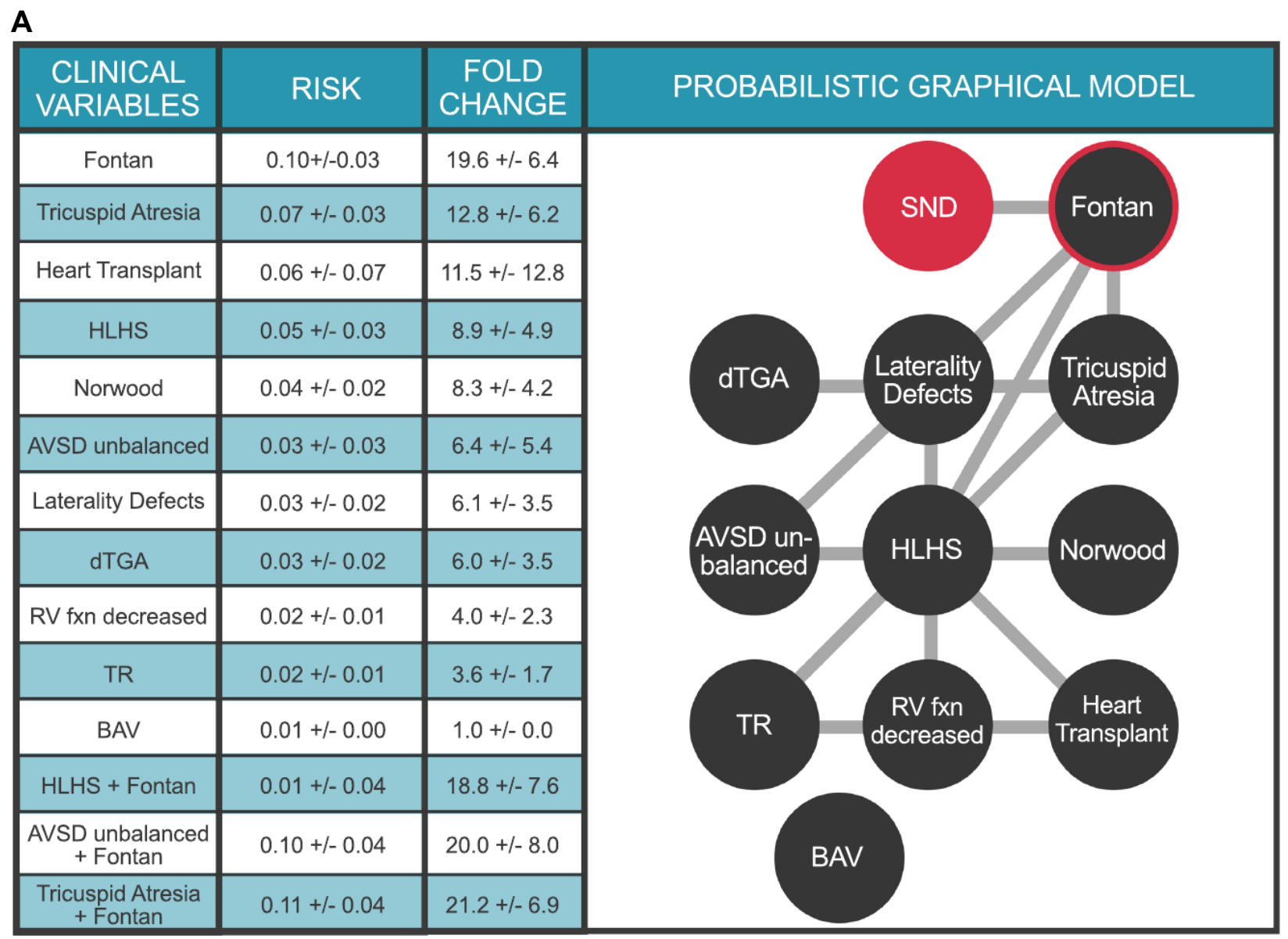

B

\begin{tabular}{|c|c|c|c|}
\hline OUTCOMES & $\begin{array}{c}\text { MARGINAL } \\
\text { RISK }\end{array}$ & $\begin{array}{c}\text { FOLD } \\
\text { CHANGE }\end{array}$ & PROBABILISTIC GRAPHICAL MODEL \\
\hline Skeletal & $0.0268+/-0.0002$ & $1.89+/-0.03$ & \\
\hline Cardiac & $0.0277+/-0.0002$ & $1.83+/-0.03$ & \\
\hline Skin & $0.0160+/-0.0001$ & $1.76+/-0.03$ & \\
\hline Downs & $0.0023+/-0.0001$ & $1.65+/-0.07$ & \\
\hline Diaphragm & $0.0009+/-0.0000$ & $1.43+/-0.05$ & \\
\hline Nervous & $0.0120+/-0.0004$ & $1.37+/-0.15$ & \\
\hline Genito-Urinary & $0.0288+/-0.0002$ & $1.34+/-0.02$ & \\
\hline Cleft Lip & $0.0014+/-0.0001$ & $1.19+/-0.06$ & \\
\hline Digestive & $0.0113+/-0.0001$ & $1.16+/-0.01$ & \\
\hline Eye & $0.0096+/-0.0001$ & $1.13+/-0.01$ & \\
\hline
\end{tabular}


medRxiv preprint doi: https://doi.org/10.1101/2021.07.21.21260474; this version posted July 22, 2021. The copyright holder for this preprint (which was not certified by peer review) is the author/funder, who has granted medRxiv a license to display the preprint in perpetuity.

Figure 4. Multimorbidity Landscape of Sinoatrial Node Dysfunction (SND). Each node represents a diagnosis or procedure, each edge represents a conditional dependence between nodes. For detailed description of the clinical variables, please refer to supplemental table 5 . Panel A. Pediatric SND. $N=26,458$ individuals. Clinical variable terms represent terms in the Primary Children's Hospital echocardiographic database or CCS billing codes when available. Fontan: Fontan surgery; HLHS: hypoplastic left heart syndrome; Norwood: Norwood surgery; dTGA: d-transposition of the great arteries; RV fxn: right ventricular function; TR: >=moderate tricuspid regurgitation; BAV: bicuspid aortic valve. Panel B. Adult SND. N = 1.6 million individuals. Clinical variable terms represent CCS billing codes. Ancestry: Western European, African American, or Other; Ethnicity: Hispanic, or non-Hispanic. DCM: Dilated cardiomyopathy; AS: Aortic stenosis; Coarctation: Coarctation of the aorta. SND is highlighted in red in both panels. The target node (SND) is colored red and nodes with direct connections to the target (ie, within the Markov blanket) are circled red. Values in Tables represent mean \pm STD. 
medRxiv preprint doi: https://doi.org/10.1101/2021.07.21.21260474; this version posted July 22, 2021. The copyright holder for this preprint (which was not certified by peer review) is the author/funder, who has granted medRxiv a license to display the preprint in perpetuity.

It is made available under a CC-BY-NC-ND 4.0 International license .

A

\begin{tabular}{|c|c|c|c|}
\hline OUTCOMES & $\begin{array}{c}\text { MARGINAL } \\
\text { RISK }\end{array}$ & $\begin{array}{c}\text { FOLD } \\
\text { CHANGE }\end{array}$ & PROBABILISTIC GRAPHICAL MODEL \\
\hline Skeletal & $0.0268+/-0.0002$ & $1.89+/-0.03$ & \\
\hline Cardiac & $0.0277+/-0.0002$ & $1.83+/-0.03$ & \\
\hline Skin & $0.0160+/-0.0001$ & $1.76+/-0.03$ & \\
\hline Downs & $0.0023+/-0.0001$ & $1.65+/-0.07$ & \\
\hline Diaphragm & $0.0009+/-0.0000$ & $1.43+/-0.05$ & \\
\hline Nervous & $0.0120+/-0.0004$ & $1.37+/-0.15$ & \\
\hline Genito-Urinary & $0.0288+/-0.0002$ & $1.34+/-0.02$ & \\
\hline Cleft Lip & $0.0014+/-0.0001$ & $1.19+/-0.06$ & \\
\hline Digestive & $0.0113+/-0.0001$ & $1.16+/-0.01$ & \\
\hline Eye & $0.0096+/-0.0001$ & $1.13+/-0.01$ & \\
\hline
\end{tabular}

B

\begin{tabular}{|c|c|c|c|}
\hline OUTCOMES & $\begin{array}{c}\text { MARGINAL } \\
\text { RISK }\end{array}$ & $\begin{array}{c}\text { FOLD } \\
\text { CHANGE }\end{array}$ & PROBABILISTIC GRAPHICAL MODEL \\
\hline ASD & $0.0205+/-0.0004$ & $1.95+/-0.20$ & \\
\hline Coarctation & $0.0024+/-0.0002$ & $1.81+/-0.36$ & \\
\hline AS & $0.0012+/-0.0001$ & $1.78+/-0.38$ & \\
\hline BAV & $0.0006+/-0.0001$ & $1.77+/-0.49$ & \\
\hline VSD & $0.0083+/-0.0003$ & $1.72+/-0.45$ & \\
\hline TGA & $0.0011+/-0.0001$ & $1.70+/-0.36$ & \\
\hline HLHS & $0.0015+/-0.0001$ & $1.69+/-0.28$ & \\
\hline TOF & $0.0009+/-0.0001$ & $1.61+/-0.27$ & \\
\hline
\end{tabular}


medRxiv preprint doi: https://doi.org/10.1101/2021.07.21.21260474; this version posted July 22, 2021. The copyright holder for this preprint (which was not certified by peer review) is the author/funder, who has granted medRxiv a license to display the preprint in perpetuity. It is made available under a CC-BY-NC-ND 4.0 International license .

Figure 5. Impact of maternal health on congenital anomalies in the child. Panel A. Multimorbidity landscape for child's risk for congenital malformations in the context of pregnancy-induced hypertension. $\mathrm{N}=125,014$ mothers. Clinical variable terms represent CCS billing codes present in the EHR database. Maternal diagnosis is highlighted in orange; HTN-Preg: Maternal diagnosis of hypertension complicating pregnancy (aka, pregnancy-induced hypertension); Diaphragm: Diaphragmatic congenital abnormalities; Genito-Urinary: Genito-Urinary congenital abnormalities; Cardiac: Cardiac and Circulatory congenital abnormalities; Skeletal: Skeletal congenital abnormalities; Down: Trisomy 21; Digestive: Congenital abnormalities of the gastrointestinal tract; Nervous: Nervous system congenital abnormalities; Eye: Congenital abnormalities of the Eye; CleftLip: Cleft lip. Panel B. Multimorbidity landscape for child's risk of congenital heart defects in the context of pregnancy-induced hypertension. $\quad \mathrm{N}=125,014$ mothers. ASD, atrial septal defect; VSD, ventricular septal defect, HLHS, hypoplastic left heart syndrome; Coarctation, coarctation of the aorta; TOF, tetralogy of fallot; BAV, bicuspid aortic valve. For detailed description of the clinical variables, please refer to supplemental table 5. The target node (HTN-PREG) is colored red and nodes with direct connections to the target (ie, within the Markov blanket) are circled red. Values in Tables represent mean \pm standard deviation. 